\title{
ACUSAÇÕES ATL ÂNTICAS: O CASO DOS ESCRAVOS NUM NAVIO FANTASMA - RIO DE JANEIRO, 1861
}

\author{
Luiz Alberto Couceiro \\ Doutorando no Programa de Pós-Graduação em Sociologia \\ e Antropologia - IFCS/UFRJ
}

\section{Resumo}

Nosso objetivo neste artigo é analisar o comércio ilegal de escravos, para o Brasil, numa perspectiva da História Atlântica. Para tanto, analisaremos documentos concernentes ao Sudeste cafeeiro das décadas de 1850 e 60 , fundamentalmente um processo criminal sobre um navio destinado àquela atividade.

\section{Palarras-Chave}

Escravidão • História Atlântica • Comércio ilegal de escravos

\section{Abstract}

The objective of this article is to analyze the illegal commerce of slaves to Brazil, from an Atlantic History perspective, through documents related to the coffee plantations of southeastern Brazil in the 1850s and $60 \mathrm{~s}$. The article is based essentially on a law suit against a vessel destined for such activity.

\section{Keywords}

Slavery $\bullet$ Atlantic history $\bullet$ Illegal commerce of slaves 


\section{A questáo e sua narrativa}

Uma das muitas e variadas maneiras de conhecermos histórias de relações entre escravos, livres e libertos no Império do Brasil é através dos relatos contidos nos processos criminais. Tais fontes não contêm aquilo que foi realmente dito, a "verdade positiva". São narrativas transcritas por membros da burocracia imperial, traduzindo as palavras dos depoentes para a linguagem jurídica de então. Entretanto, o dialeto social das relações entre pessoas e grupos pode ser em parte conhecido através da linguagem jurídica inquisitorial, investigativa, fruto da tentativa de arrancar a verdade policial do interior dos potencialmente criminosos, até que fosse provado o contrário ${ }^{1}$. Não é de hoje que a historiografia internacional se dedica a formular métodos de estudo, pesquisa e escrita sobre a construção de relações sociais, aproveitando as fontes escritas produzidas, direta ou indiretamente, por aparelhos institucionais repressivos. Em estudos significativos é possível mencionar a utilização de fontes tais como processos inquisitoriais sobre cosmologia popular de um moleiro em Friuli, no século XVI, desafiadora da interpretação única da Igreja sobre o universo; depoimentos de acusados de heresia nos Pirineus, fruto da perseguição da Inquisição, no século XIV; documentos cartoriais sobre disputas de terra ao redor da figura de um exorcista na cidade de Santena, no século XVII; cartas de pedidos de perdão por crimes como último recurso ao Rei de França e a literatura clandestina na França do século XVIII, antes mesmo da eclosão da Revolução de $1789 .^{2}$

\footnotetext{
${ }^{1}$ Para exemplos de autores que trabalharam com processos criminais sob esta lógica, ver: CHALHOUB, Sidney. Visões da liberdade: uma história das últimas décadas da escravidão na Corte. São Paulo: Companhia das Letras, 1990; COUCEIRO, Luiz Alberto. Bumerangue encapsulado: um estudo sobre a construção social da subjetividade numa cidade escravista, Rio de Janeiro, c.1860-c.1888. Rio de Janeiro: 7Letras, 2003; MACHADO, Maria Helena Pereira Toledo. Crime e escravidão: trabalho, luta e resistência nas lavouras paulistas, 18201888. São Paulo: Brasiliense, 1987 e O plano e o pânico: os movimentos sociais na década da abolição. Rio de Janeiro/São Paulo: Editora UFRJ/EDUSP, 1994.

${ }^{2} \mathrm{Na}$ ordem dos assuntos apresentados, cf.: GINZBURG, Carlo. O queijo e os vermes: o cotidiano e as idéias de um moleiro perseguido pela Inquisição. São Paulo: Companhia das Letras, 1996; LADURIE, Emmanuel Le Roy. Montaillou: povoado occitânico, 12941324. São Paulo: Companhia das Letras, 1997; LEVI, Giovanni. A herança imaterial: a trajetória de um exorcista no Piemonte do século XVII. Rio de Janeiro: Civilização Brasileira, 2000; DAVIES, Natalie. Histórias de perdão e seus narradores na França do século XVI. São Paulo: Companhia das Letras, 2001 e DARNTON, Robert. Edição e sedição: o universo da literatura clandestina no século XVIII. São Paulo: Companhia das Letras, 1992.
} 
Em alguma medida, esses autores se detiveram na análise de documentos construídos a partir de uma acusação: heresia, feitiçaria, pacto com o diabo, crimes de assassinato e subversão política. Uma vez feita oficialmente, a acusação desencadeia um processo de relações entre fatores os mais diversos, por pares de oposição, metáfora, e semelhança, metonímia, relembrando as já consagradas categorias de Lévi-Strauss. ${ }^{3}$ No caso do pensamento ordenado pela metáfora, as comparações são infinitas, posto que tudo no cosmos faz sentido. Nesta forma de pensamento, a construção mental está mais ligada às sensações. No caso do pensamento ordenado pela metonímia, as comparações são finitas, estabelecidas por conceitos, substituindo o efeito pela sua causa. Mas, o que podemos tirar disso?

Como bem lembraram Mauss \& Durkheim, a atividade classificatória pode iludir a muitos que seja individual, mas trata-se de um fenômeno da coletividade, produto da vida social, unindo as idéias entre si no processo de construção das formas de percepção e conhecimento do homem sobre os fenômenos sociais. ${ }^{4}$ Pensemos, assim, quando algum comportamento é classificado, por autoridades reconhecidas por instituições repressoras, como condenável, errado ou perigoso. A pessoa acusada deve ser afastada do convívio social, posto que ela corresponde ao tal comportamento - pacto com diabo, desafiar a leitura única do mundo da Igreja, blasfemar o Estado francês, por exemplo. Por conseguinte, a pessoa se comporta no sentido contrário ao de seus acusadores, uma vez que são eles os “donos” do sistema de classificação. Teríamos, assim, uma metáfora. Por outro lado, teríamos uma metonímia no caso do tribunal da Inquisição, como exemplo de aparelho repressor, cada vez mais conceituar numa certa categoria um número variado de comportamentos. É neste sentido que trabalharemos.

\footnotetext{
${ }^{3}$ LÉVI-STRAUSS, Claude. Totemismo hoje. In: Lévi-Strauss. São Paulo: Abril Cultural, 1976, pp. 95-187, Coleção Os Pensadores, vol. L. Esta discussão estende-se em LÉVI-STRAUSS, Claude. O pensamento selvagem. 2a. Edição. Campinas: Papirus, 1997, princ. "1 - A ciência do concreto", pp. 15-49. Sobre outras possíveis conexões entre conceitos de Lévi-Strauss e a História como disciplina, ver GOLDMAN, Márcio. "Lévi-Strauss e os sentidos da história." In: Alguma antropologia. Rio de Janeiro: Relume-Dumará, 1999, pp. 55-64.

${ }^{4}$ DURKHEIM, Émile \& MAUSS, Marcel. "Algumas formas primitivas de classificação.” In: MAUSS, Marcel. Ensaios de sociologia. 2. Edição. São Paulo: Perspectiva, 1999, pp. 399-455.
} 
Afinal de contas, todo processo criminal, ao menos no Império do Brasil, é desencadeado por uma acusação formal, oficializada pela Justiça, após a investigação policial. Acusador e acusado serão nossos personagens, e temos que saber o mínimo sobre seus perfis sociais, bem como o clima social no qual se encontraram, no momento em que se confrontaram, gerando um documento.

Desta forma, perguntamos: no Império do Brasil, seria possível uma autoridade destas instituições inquisitoriais ser acusada, neste mesmo processo de produção da verdade? Nosso objetivo é construir a resposta de tal pergunta através do estudo do que chamamos "acusação atlântica", um tipo de acusação que só pode ser feita, pois só faz sentido, no momento em que as pessoas em relação compreendem que fazem parte de uma rede de relação internacional, como, por exemplo, numa legislação que abarca várias regiões do mundo. A atividade do comércio de escravos ligava pessoas de origem diversa, comportamentos e línguas as mais variadas, produzindo novos ambientes de convivência, como os navios negreiros - que transportavam informações e culturas construídas em seu interior. ${ }^{5}$ Estes vários ambientes não podem ser sufocados através abordagens que levem em conta culturas subordinadas a territórios nacionais, pura e simplesmente. Em se tratando de "acontecimentos hemisféricos", como o tráfico internacional de escravos, havia intensa comunicação entre os sujeitos envolvidos, desde autoridades preocupadas em reprimir tal atividade, outras preocupadas em lucrar com a mesma e até mesmo marinheiros, os próprios escravos e senhores de muitas plantations. ${ }^{6}$ Várias pontas do Atlântico juntam-se em eventos

\footnotetext{
${ }^{5} \mathrm{O}$ navio como metáfora é utilizado por nós no sentido de GILROY, Paul. O Atlântico negro: modernidade e dupla consciência. Rio de Janeiro, São Paulo: Centro de Estudos Afro-Asiáticos/UCAM, Editora 34, 2000, p. 38.

${ }^{6}$ Para maior análise do chamado mundo atlântico, ver LINEBAUGH, Peter. Todas as montanhas atlânticas estremeceram. Revista Brasileira de História. São Paulo: ANPUH, Marco Zero, n. 6, setembro de 1983, pp. 7-46. Ver também o aprofundamento do debate em SWEENY, Robert. Outras canções de liberdade: uma crítica de "Todas as montanhas atlânticas estremeceram" e LINEBAUGH, Peter. "Réplica". Revista Brasileira de História. São Paulo: ANPUH, Marco Zero, v. 8, n. 16, março/agosto de 1988, pp. 205-231. Sobre uma aplicação sistemática deste debate para o período próximo ao que vamos trabalhar, ver SOARES, Carlos Eugênio Líbano \& GOMES, Flávio dos Santos. Sedições, haitianismo e conexões no Brasil: outras margens do Atlântico negro. Novos Estudos CEBRAP, n. 63, julho de 2002, pp. 131-144 e GOMES, Flávio dos Santos. Experiências transatlânticas e significados locais: idéias, temores e narrativas em torno do Haiti no Brasil escravista. Revista Tempo. Rio de Janeiro, v. 7, n. 13, 2002, pp. 209-246. Sobre a percepção senhorial acerca da politização dos escravos no contexto de insurreições nas Américas, com informações interpretadas no âmbito internacional, ver GENOVESE, Eugene. Da revolução à
} 
como os que vamos narrar e, embora cada lugar tenha as suas especificidades no envolvimento com o tráfico de escravos, os sujeitos não estavam alheios ao que pensavam sobre acontecimentos políticos noutros lugares também envolvidos com aquele comércio. Mais do que pensar o Atlântico como um grande e único sistema econômico, pensemos como área de circulação de idéias políticas e outras mais. ${ }^{7}$

\section{O navio: palco de um "assassino", de uma "vítima" e das outras em potencial}

Manoel José de Campos, juiz de Direito de Macaé, estava sendo processado "justamente pelo zelo com que, sacrificando os seus cômodos, tratou alta noite de impedir que um homem ébrio ou malvado, depois de praticar um delito, continuasse a praticar outros" ${ }^{8}$ A altas horas da madrugada do dia dez de maio de 1861, conta Manoel José que foi avisado pelo capitão de um barco que em seu navio se dera um delito. O "delinqüente", contou o tal capitão, se preparava para cometer outros delitos. Já o havia colocado a ferros há dois dias, em seu navio, mas isso ainda não o havia acalmado. Por isso, o juiz foi acordado com o pedido de expedir uma patrulha o mais rápido possível para o navio, a fim de impedir maior tragédia. Foi o que Manoel José fez, conseguindo prender o delinqüente, instaurando processo contra o mesmo, deixando o capitão do navio "muito satisfeito com aquelas providências".

rebelião. São Paulo: Global, 1983, pp. 25-61. Para um grande panorama dos debates diversos sobre a perspectiva teórico-metodológica da História Atlântica, ver CANNY, Nicholas. Writing Atlantic History, or, Reconfiguring the History of Colonial British America. The Journal of American History, v. 86, n. 3, The nation and beyond: transnational perspectives on United States History. A special issue. Dec. 1999, pp, 1093-1114, e, para um resumo da perspectiva teórica da história atlântica ver THORNTON, John. A África e os africanos na formação do mundo atlântico, 1400-1800. Rio de Janeiro: Campus, 2004, pp. 41-50".

${ }^{7}$ Ver LAW, Robin \& MANN, Kristin. West Africa in the Atlantic community: the case of the slave coast. The William and Mary Quarterly, 3rd. Series, v. 56, n.2, African and American Atlantic Worlds, apr., 1999, pp. 307-334. Uma abordagem econômica e comparativa do Atlântico para o tráfico de escravos em relação com os motivos materiais da adoção da mão-de-obra compulsória africana nas Américas pode ser encontrada em MENARD, Russel R. \& SCHWARTZ, Stuart B. "Por que a escravidão africana? A transição da força de trabalho no Brasil, no México e na Carolina do Sul.” In: SZMRECSÁNYI, Tamás (org.), História econômica do período colonial: coletânea de textos apresentados no I Congresso Brasileiro de História Econômica (Campus da USP, setembro de 1993). São Paulo: HUCITEC, FAPESP, 1996, pp. 3-19.

${ }^{8}$ Arquivo Nacional, doravante AN, Corte de Apelação, Traslado, caixa 130, n. 374, galeria C. 
Após estes fatos, o navio se ausentou do porto de Macaé. As demais providências não puderam ser tomadas, uma vez que as investigações deveriam ser feitas no interior do navio. Assim, Manoel José teve que esperar seu regresso. O problema técnico que havia no processo era simplesmente o fato da prisão ter sido feita sem flagrante delito, ou seja, baseada apenas nas denúncias do capitão do navio, confirmadas por sua tripulação. Depoimentos oficiais não foram colhidos, apenas informais. Isso gerou um processo do preso contra o juiz Manoel José. O documento que achamos, único sobre o caso, é parte transcrita deste processo - Traslado - na qual o juiz queixa-se exatamente de uma "injustiça" cometida contra sua "figura pública".

Todos os informantes, os marinheiros, eram escravos, segundo afirmou o capitão do navio, que não voltou para ver o que havia acontecido com o "delinqüente". Ao que tudo indica, tratava-se de alguém que não se adequava mais àquela embarcação, sendo despejado de maneira legal em algum porto do Império do Brasil, uma vez que o navio vinha de Cuba - mas com o "capitão falando português claro", segundo o juiz relatou. Além de o navio passar incólume pela costa brasileira, tudo ocorreu como se não tivesse estado por aqui. O que ficou de tudo isso foram os relatos do preso, bem como os dos policiais que foram até o navio executar a prisão. O juiz viu a embarcação, e não apenas falou com o seu capitão. Algumas pessoas da cidade de Macaé, segundo o juiz, "são testemunhas de seu ato de justiça e zelo pela ordem pública". Foram muitas as que viram o navio, e presenciaram a tumultuada cena da prisão.

Mas, perguntemos, alguém viu os marinheiros escravos? Alguma autoridade registrou a passagem do navio pelo Brasil? Alguém sabia o nome de algum dos seus tripulantes? É compreensível, desta forma, que não haja documento algum para o pesquisador trabalhar dados sobre este navio, uma vez que nem mesmo as autoridades imperiais os tinham para construir o processo criminal contra o suposto "delinquiente". Desta forma, podemos dizer que se tratava e trata-se de um navio fantasma com escravos, a princípio marinheiros, rapidamente vistos pelos poucos policiais que estiveram a seu bordo.

\section{O clima social de nossa história}

Relembremos, sumariamente, as leis e seus devidos impactos para o final do comércio Atlântico de escravos para o Brasil, para abrirmos novas questões em nosso caso. 
Em 1810, mais precisamente em 19 de fevereiro, os governos de Portugal e Inglaterra assinaram o tratado de Aliança e Amizade. Na cláusula X, D. João, regente de Portugal, e Lord Strangford, enviado inglês à corte portuguesa, confessavam-se plenamente convencidos da injustiça e má política do comércio de escravos. A coroa portuguesa comprometia-se a colaborar com a supressão do comércio de escravos, proibindo seus súditos de comerciá-los em territórios africanos que não pertencessem a ela. Entretanto, vale ressaltar que, aos súditos portugueses foi conservado o direito de traficar escravos nos domínios lusitanos na África. ${ }^{9}$ Muitos membros da burocracia inglesa ligados ao comércio marítimo reclamaram que os traficantes portugueses não eram bem policiados por Portugal, e um forte indício da má-vontade do governo desse país em cumprir o tratado pode ser a dificuldade que o governo inglês teve para conseguir passar aquela proibição. ${ }^{10}$ Desde 1807 , o governo inglês já havia proscrito a participação de súditos ingleses no tráfico de escravos, iniciando imediata campanha militar e diplomática contra o mesmo. Portanto, há mais tempo do que a assinatura dos tratados de 1810, o governo inglês pressionava o de Portugal para aderir à campanha contra o comércio de escravos.

Em 21 e 22 de janeiro de 1815, ambos governos firmaram novo tratado delimitando precisamente em quais territórios o comércio de escravos seria proibido na costa da África. Mais uma vez, constava neste tratado o compromisso de que ambas nações agiriam juntas para a gradual supressão do comércio de escravos. O príncipe regente de Portugal proibia que seus vassalos comerciassem ou comprassem escravos em qualquer parte da África ao norte do Equador. Em 1817, uma convenção dava direitos a ambos governos de dar buscas em navios um do outro, para verificar a mínima suspeita de tráfico de escravos. Esta situação radicalizou, em março de 1823, com um artigo adicional àquela convenção que decidia que navios de traficantes apresados pelos cruzadores daquelas marinhas seriam condenados pelos Comissários.

Em 23 de novembro de 1826, novo tratado entre Brasil e Inglaterra marcou a pressão deste último país a fim de impedir que súditos do Império do

\footnotetext{
${ }^{9}$ Cf. BETHELL, Leslie. A abolição do tráfico de escravos no Brasil: a Grã-Bretanha, o Brasil e a questão do tráfico de escravos. Rio de Janeiro, São Paulo: Expressão e Cultura, Editora da Universidade de São Paulo, 1976, p. 22.

${ }^{10}$ Cf. MANCHESTER, Alan K Preeminência inglesa no Brasil. São Paulo: Brasiliense, 1973, pp. 151-154.
} 
Brasil comerciassem escravos na costa da África, sendo considerado pirataria. Parte deste tratado serviu de base para a lei de 7 de novembro de 1831, afirmando que todos os africanos que foram vendidos como escravos no Brasil, desde esta data, seriam considerados libertos. Além disso, os traficantes seriam punidos com multa e a pena de reexportar os libertos de volta para a África. Até 1845, deram-se algumas reuniões entre representantes dos governos de Brasil e Inglaterra para negociar com menor ou maior afinco, respectivamente, o final do comércio de escravos da África para o Brasil. Naquele ano, além do governo inglês reforçar aquela atividade comercial como pirataria, alegava ter o direito de dar buscas em navios suspeitos de traficar escravos, bem como sujeitar aos tribunais do Almirantado e Vice-Almirantado, em seus domínios, os navios brasileiros comprovadamente dados ao tráfico. Era o Bill Aberdeen, aplicado com vigor pelo governo inglês, e sentido por uma série de traficantes de escravos com as freqüentes perdas comerciais. ${ }^{11}$

Em 1850, finalmente o Império do Brasil resolveu que não mediria esforços para fiscalizar a aplicação de uma nova lei, que proibiria o tráfico internacional de escravos. Em fins de 1849, o então chefe de polícia do Rio de Janeiro, Eusébio de Queiroz, preveniu traficantes de escravos de que isso realmente ocorreria no ano seguinte. Temendo que não lhe dessem crédito, mandou a polícia dar incursões de apreensão e fechar os principais depósitos de escravos, nos arredores da Corte. ${ }^{12}$

Até então, desembarques clandestinos eram realizados com a cumplicidade de uma série de agentes do Estado corrompidos por traficantes e grandes senhores de escravos - fugindo, em grande parte, da fiscalização exercida por funcionários da marinha inglesa. Os agentes que tentavam aplicar as leis a rigor eram, freqüentemente, hostilizados pelos corruptos, demitidos e até mesmo assassinados. $\mathrm{O}$ abuso de funcionários da marinha e do exército brasileiros era tal que muitos alugavam instalações do governo para servirem de depósitos de escravos. Em 1838 e 1839, por exemplo, um certo coronel Vasques, comandante da fortaleza de São João - localizada à entrada do porto do Rio de Janeiro - trans-

\footnotetext{
${ }^{11}$ Para um resumo destas e de outras leis antitráfico de escravos, da conjuntura diplomática entre Brasil e Inglaterra bem como algumas outras nações que participavam do comércio negreiro, ver GOULART, Maurício. A escravidão africana no Brasil: das origens à extinção do tráfico. $3^{a}$. edição revista. São Paulo: Alfa-Ômega, 1975, pp. 219-263. ${ }^{12}$ Cf. BETHELL, Leslie. A abolição do tráfico de escravos no Brasil, p. 301.
} 
formou-a num destes depósitos. Em sociedade com um tal coronel Tota, que controlava um outro depósito, situado na baía de Botafogo, conseguiu que 12.570 escravos fossem desembarcados no Brasil. ${ }^{13}$ Pessoas eram contratadas pelos traficantes para observarem a costa brasileira, dando sinal para que pequenas embarcações, num momento de menor atenção dos ingleses, levassem os escravos para o continente. Os escravos iam para lugares já preparados para recebê-los, onde eram vestidos como se fossem escravos já há tempo no Brasil e enviados para seus compradores nas casas de leilão localizadas na Corte. Enquanto isso, os tumbeiros eram pintados e reformados para não dar na vista sua real função mercantil, seguindo para ganhar lastro na alfândega do Rio de Janeiro. ${ }^{14}$

Apesar destes problemas, quanto maior as campanhas e a repressão oficiais contra o comércio de escravos para o Brasil, menos prestigiada era a imagem do traficante: de comerciantes ricos e influentes, passaram a piratas vorazes e indignos de se manterem no Brasil. Além disso, muitos políticos viam na ação dos traficantes a semente da grande leva de corrupção entre funcionários de vários escalões do governo. ${ }^{15}$ Nos anos de 1830, pode-se até mesmo falar numa "comunidade de traficantes", posto que faziam parte de uma íntima rede de relações sociais: ocupavam cargos públicos de confiança, eram as grandes fortunas da Corte, as relações entre os traficantes transbordavam do âmbito comercial para o pessoal e afetivo, caracterizando um tipo de negócio que rezava mais pelas relações pessoais de confiança, do que pelas impessoais puramente econômicas. ${ }^{16}$

Em 4 de setembro de 1850, o projeto de lei para o final do tráfico internacional de escravos para o Brasil, discutido desde 1848, era sancionado em lei pelo Imperador Pedro II. Desde então, conforme rezava o texto do artigo primeiro, os navios brasileiros, onde quer que fossem encontrados, e os navios estrangeiros descobertos em portos, baías, ancoradouros e águas territoriais do Brasil, que esti-

\footnotetext{
${ }^{13}$ Cf. CONRAD, Robert. Tumbeiros: o tráfico escravista para o Brasil. São Paulo: Brasiliense, 1985, p. 126.

${ }^{14}$ Cf. CONRAD, Robert. Tumbeiros, p. 130.

${ }^{15}$ RODRIGUES, Jaime. O infame comércio: propostas e experiências no final do tráfico de africanos para o Brasil (1800-1850). Campinas: Editora da UNICAMP, CECULT, 2000, pp. 127-132.

${ }^{16}$ Este conceito é construído e desenvolvido por FLORENTINO, Manolo. Em costas negras: uma história do tráfico de escravos entre a África e o Rio de Janeiro (séculos XVIII e XIX). São Paulo: Companhia das Letras, 1997, princ. p. 204 em diante.
} 
vessem transportando escravos eram passíveis de captura pelas autoridades brasileiras. A importação de escravos para o Brasil era, assim, declarada pirataria. Uma série de artigos impunha punições severas aos cúmplices dos traficantes - como a tripulação dos navios e funcionários do Estado - e legislava sobre o destino dos africanos recuperados pelo Brasil - isto é, trabalhar para o Estado até serem reexportados com custas pagas pelo mesmo. Decretos seguintes à lei a complementaram, como o de 14 de novembro, no qual o governo determinava os critérios para que um navio fosse considerado tumbeiro. ${ }^{17}$

Mesmo assim, muitos dos envolvidos no tráfico de escravos duvidaram do peso da nova lei em seus negócios. Até o caso do porto do Bracuhy, em Angra dos Reis, bem perto da Corte, envolvendo importantes figuras políticas do Império e prósperos cafeicultores.

O Diário do Rio de Janeiro noticiava, em 11 de dezembro de 1852, a existência de forte boato acerca do desembarque de africanos no porto do Bracuhy, em Angra dos Reis. No mês de janeiro, as autoridades policiais confirmaram a notícia, após denúncia feita pelo delegado de polícia de Angra em carta de 22 de dezembro ao ministro dos Negócios da Justiça, José Ildefonso de Sousa Ramos - substituto de Eusébio de Queiroz. Segundo a carta, escravos foram desembarcados de um navio comandado por um capitão norte-americano, rumo à fazenda Santa Rita, do comendador Joaquim José de Sousa Breves nosso conhecido de outros trabalhos. Depois disso, o barco havia sido queimado em alto-mar. Ainda em janeiro, o ministro informa ao Imperador que dois marinheiros norte-americanos, um espanhol e outro inglês haviam sido presos. Todos trabalhavam no tumbeiro Camargo, e confessaram ter participado do desembarque de mais de 500 africanos no porto do Bracuhy. ${ }^{18}$

O delegado de polícia local, Manuel de Aguiar Vallim, também era dono de grande quantidade de terras e escravos - segundo vários indícios, havia relação direta entre seu enriquecimento e o lucrativo tráfico de escravos africanos. ${ }^{19}$ Seu envolvimento com o caso repercutiu na imprensa local e na Corte.

\footnotetext{
${ }^{17}$ Cf. BETHEL, Leslie. A abolição do tráfico de escravos no Brasil, p. 323-324.

${ }^{18}$ Cf. ABREU, Martha. "O caso do Bracuhy." In: CASTRO, Hebe Maria Mattos de \& SCHNOOR, Eduardo (orgs.). Resgate: uma janela para o oitocentos. Rio de Janeiro: Topbooks, 1995, pp. 165-195, p. 167.

${ }^{19}$ Cf. FARIA, Sheila de Castro. "Fortuna e família em Bananal no século XIX." In: CASTRO, Hebe Maria Mattos de \& SCHNOOR, Eduardo (orgs.). Resgate: uma janela para o oitocentos. Rio de Janeiro: Topbooks, 1995, pp. 63-97, pp. 71-72.
} 
Diante da Justiça, Vallim afirmou que não havia tomado atitudes mais enérgicas diante da denúncia daquele desembarque de africanos por saber que autoridades do governo imperial já haviam se antecipado. Um contingente policial entre 300 e 400 praças foi enviado para patrulhar a região de Angra dos Reis e cercanias - como a cidade de Bananal, onde ficava a Resgate, maior das fazendas de Vallim. ${ }^{20}$ Uma das conclusões do ministro dos Negócios da Justiça era de que o desembarque havia acontecido na Resgate, segundo os próprios escravos traficados e compradores locais, como o fazendeiro Francisco Ramos de Paula. ${ }^{21}$ Além disso, o substancial contingente policial assegurava que grande insurreição de escravos poderia ser contida, caso os boatos fossem confirmados. Após a intervenção do Estado nas fazendas onde escravos do caso do Bracuhy haviam sido ilegalmente comprados, outros mais daquelas cercanias passaram a acreditar que teriam o mesmo direito. Assim, fugas de escravos aumentavam a cada dia. Escravos presos confessaram que apenas estavam exercendo seu direito à liberdade, assim como os africanos libertados de Resgate e d'outras fazendas mais. ${ }^{22}$

O governo do Estado estava disposto a impedir a continuidade do tráfico de escravos para o Brasil, e nisso o caso do porto do Bracuhy foi paradigmático para a época. Foram cerca de 3 meses de investigações e manobras políticas tanto dos que lutavam pela condenação, quanto dos que lutavam pela absolvição dos políticos envolvidos diretamente no caso. Mesmo em se tratando de um paradoxo do ponto de vista econômico, isto é, o governo de uma nação de mãode-obra majoritariamente escrava lutando contra o comércio de escravos, as pressões contra os senhores de escravos havia diminuído bastante a importação dos mesmos. Do ponto de vista político, este Estado queria mostrar que era ele, e não os grandes proprietários de terras e escravos, bem como os traficantes, que mandava no governo da nação, dizendo o momento certo de tomar atitudes contra o trabalho escravo.

Após a supressão do tráfico internacional de escravos para o Brasil, em 1850, o medo senhorial no sudeste girava em torno do choque entre os escravos comprados das províncias do norte e os que já estavam nas fazendas do

\footnotetext{
${ }^{20}$ Cf. ABREU, Martha. "O caso do Bracuhy”, pp. 177-183 e p. 187.

${ }^{21}$ Cf. ABREU, Martha. "O caso do Bracuhy”, p. 177.

${ }^{22}$ Cf. ABREU, Martha. "O caso do Bracuhy”, pp. 189.
} 
sudeste. ${ }^{23} \mathrm{O}$ tráfico e o comércio internos de escravos já eram realizados há muito tempo entre as regiões da Luso-América e as do Império do Brasil, mas haviam se intensificado com o cumprimento da lei de 1850 sendo fiscalizado pelo governo. Nos primeiros anos daquela década, o então ministro da Justiça, Eusébio de Queiróz, pedia relatórios mensais a chefes de polícia de cidades como Angra dos Reis e Parati, oferecendo toda à ajuda necessária para combater o tráfico. Ao menos até 1853, aqueles relatórios foram rotina, do mesmo modo que notícias motivadas por boatos sobre possíveis desembarques de africanos. Uma destas veio três anos após a lei. No dia 25 de janeiro de 1853, o comandante superior da Guarda Nacional de Parati envia uma carta ao presidente da província do Rio de Janeiro afirmando que "as suspeitas sobre um possível desembarque de africanos naquela região são fundadas". Esta informação mobilizou durante semanas diversas autoridades locais, tendo o comandante superior aventado a possibilidade de reformular as "estratégias dos batalhões da região, visto terem melhor treinamento para este tipo gravíssimo de situação". ${ }^{24}$

Durante toda a década seguinte, notícias de desembarque de africanos continuavam a mobilizar autoridades em vários portos do Rio de Janeiro. Em maio de 1863, o juiz de Direito da comarca de Angra dos Reis, Teófilo Ribeiro de Rezende, escreve um documento "Reservado" ao então presidente da província do Rio de Janeiro, Policarpo Lopes de Leão. Na carta, o juiz afirma que recebeu a Circular Reservada com data de 13 daquele mês, expedida por Policarpo, sobre notícia de tráfico de escravos vindo de Angola, enviada pelo cônsul do Brasil naquele país. O alerta sobre a ação de "contrabandistas" especializados fez com que o juiz lembrasse o tamanho da costa do Rio de Janeiro, e "seus inúmeros portos, enseadas e lugares apropriados para o desembarque de escravos africanos". Por isso, recomendou, novamente, segundo afirma, a implantação de um navio cruzeiro ativo, sem o qual a vigilância continuaria precária. ${ }^{25}$

\footnotetext{
${ }^{23}$ Cf. COUCEIRO, Luiz Alberto. Reinventando o cativeiro, construindo a emancipação: escravos, senhores e lógicas de sociabilidade em fazendas de café (Sudeste, 1860-1888). Revista Acervo: o Arquivo Nacional e seus pesquisadores. Rio de Janeiro: Arquivo Nacional, v. 15, n. 2, 2002, pp. 17-32 e A disparada do burro e a cartilha do feitor: lógicas morais na construção de redes de sociabilidade entre escravos e livres em fazendas do sudeste, 1860-1888. São Paulo: Revista de Antropologia - USP, n. 46 (1), 2003. pp. 41-83.

${ }^{24}$ Arquivo Público do Estado do Rio de Janeiro, doravante APERJ, fundo PP, coleção 82.

${ }^{25}$ APERJ, PP, coleção 82.
} 
Os portos do Rio de Janeiro viviam sob forte tensão com a chegada de navios com tripulação de africanos, ou mesmo de escravos. A palavra marinheiro, naqueles anos, escondia a origem social da pessoa. Somente em 1869, por exemplo, o português Antonio Maria Teixeira de Mello, "sequiestrador" de escravos que atuava nos portos de todo o Rio de Janeiro, foi preso sob o disfarce de marinheiro. ${ }^{26}$ Tal categoria era máscara bastante eficaz para transfigurar a identidade de um escravo fugitivo de outra região do Império ou do Atlântico e até mesmo um criminoso de guerra. Costume antigo da marinharia no Atlântico, era possível que até mesmo um dialeto naval, o pidgin, tenha sido construído e utilizado no comércio internacional de escravos - há indícios de que era falado nas negociações entre traficantes na costa africana, desde o século XVII. ${ }^{27}$ Já foi constatado que os navios ingleses, no século XVIII, por exemplo, carregavam marinheiros franceses, alemães, portugueses, espanhóis, asiáticos, americanos e africanos - algumas vezes sujeitos que escondiam sua condição de escravo fugitivo, outras vezes escravos que trabalhavam nos navios - a serviço da Rainha Britânica. ${ }^{28}$ Nas correntes nem sempre calmas das pesquisas nos arquivos, cruzamos em vários momentos com pessoas escondidas não somente nas páginas de documentos, mas sob o signo marinheiro. Naquela época, muitos marinheiros aparecem na documentação como escravos, e, muitas vezes, encontramos escravos trabalhando como marinheiros em navios destinados ao tráfico. ${ }^{29}$

Naveguemos por uma destas correntes de mares passados.

\footnotetext{
${ }^{26}$ AN, IIIJ7-152, Casa de Correção do Distrito.

${ }^{27}$ Cf. LOVEJOY, Paul E. \& RICHARDSON, David. Trust, pawnship, and atlantic history: the institutional foundations of the Old Calabar slave trade. The American Historical Review, v. 104, n. 2, apr. 1999, pp. 333-355, p. 341 e THORNTON, John K. African dimensions of the Stono rebellion. The American Historical Review, v. 96, n. 4, oct. 1991, pp. 1101-1113. ${ }^{28}$ RADIKER, Marcus. "Under the banner of King Death": the social world of Anglo-American pirates, 1716-1726. The William and Mary Quarterly, 3 ${ }^{\text {rd }}$. Series, n. 38, 1981, pp. 203-227. Para informações sobre a vida no interior dos navios, ver RITCHIE, Robert C. Capitão Kidd e a guerra contra os piratas. Rio de Janeiro: Campus, 1989, pp. 117-130.

${ }^{29}$ Cf. RODRIGUES, Jaime. Cultura marítima: marinheiros e escravos no tráfico negreiro para o Brasil (sécs. XVIII e XIX). Revista Brasileira de História. São Paulo, v. 19, n. 38,1999 , pp. 15-53, p. 23. Muitas informações sobre a vida de escravos e libertos marinheiros, nos Estados Unidos da América, podem ser encontradas em BOLSTER, W. Jeffrey. "To feel like a man": black seamen in the Northern States, 1800-1860. The Journal of American History, v. 76, n. 4, mar. 1990, pp. 1173-1199.
} 


\section{0 espectro deste navio pode ser visto?}

Foucault afirmou diversas vezes que o corpo visto como detentor de verdade poderia ser regulado e manipulado pelas instituições oficiais de construção da verdade. ${ }^{30}$ Ressaltemos, porém, que no bojo de tais instituições, longe de serem máquinas com perfeito funcionamento, havia querelas entre os construtores da tal verdade objetiva, disputando os modos pelos quais e quem enquadraria os acusados nos artigos dos códigos morais e éticos. Os exemplos são múltiplos. Para ficarmos apenas com um, lembremos a Inquisição portuguesa como arena de disputas burocráticas por altos postos da hierarquia de condenação e punição dos acusados de serem feiticeiros e bruxos na Europa, até o início do século XIX. ${ }^{31}$

O tal "delinqüente" do navio fantasma teve seu corpo entregue ao controle do Estado. Foi uma pessoa controlada pelas correntes da instituição Imperial, da Justiça. Tratava-se de um homem que já estava preso por correntes de ferro, que o capitão e sua tripulação de "escravos marinheiros" afirmaram ameaçar a todos no navio, mas que ninguém viu cometer agressão alguma. De oficial mesmo, em nosso caso, somente a denúncia de um preso que acusou um juiz de tê-lo prendido por um fato supostamente ocorrido dentro de um navio que juridicamente não existia. Em virtude de todos estes fatos, tornemos o navio menos fantasma.

Seguindo informação fornecida pelo capitão ao juiz, admitamos que o navio vinha de Cuba, com "escravos cubanos", de outras ilhas do Caribe ou mesmo vindos dos Estados Unidos. Isso seria possível naqueles anos de maior fiscalização, porém não tão eficaz quanto se acredita, na costa do Rio de Janeiro?

Onze anos após ser promulgada a lei Eusébio de Queiróz, de setembro de 1850 , e realmente colocada em prática pela vontade de fiscalizar das autoridades imperiais, e não somente pelas da marinha britânica em constante vigilância em alto mar, uma "Circular Reservada" é expedida pelo ministro dos Negócios da Justiça para os chefes de polícia das províncias. ${ }^{32}$ Recebida pelo chefe

\footnotetext{
${ }^{30}$ FOUCAULT, Michel. 1999. "O olho do poder.” In: Microfísica do poder. 14". Edição. Rio de Janeiro: Graal: 209-226 e A verdade e as formas jurídicas. 2ª Edição. Rio de Janeiro: NAU, Depto. de Letras - PUC/RJ, 1999.

${ }^{31}$ BETHENCOURT, Francisco. História das Inquisições: Portugal, Espanha e Itália, séculos XV-XIX. São Paulo: Companhia das Letras, 2000.

${ }^{32}$ APERJ, PP, col. 5.
} 
de polícia da Corte, em 18 de fevereiro daquele ano, 1861, embora escrita no dia 12, a carta fala a tais autoridades sobre desembarques de escravos nos portos de Benguela e do Rio Cuanza, ao sul de Angola. O autor dos mesmos seria "um tal Oliveira Botelho, que foi outrora naquela cidade o consignatário dos navios negreiros Orytra e Pedreira, que navegam para este Império e para Havana". A recomendação era que os chefes de polícia das províncias realizassem investigações acerca de quais pessoas tinham relações, e de que natureza eram, com o respectivo traficante, pois isso confirmaria a hipótese dele se dirigir para o Rio de Janeiro.

Cuba teve seu primeiro grande boom do açúcar entre 1790 e 1820, em virtude de técnicas mais modernas de plantio e colheita introduzidas pelos franceses. O tráfico de escravos acompanhou este aumento da produtividade, uma vez que os senhores de engenho, em número vertiginosamente crescente, passaram a comprar uma quantidade maior de jovens africanos. Entre 1830 e 1860, Cuba tornou-se o maior produtor mundial de açúcar, fruto de avanços tecnológicos, como a implantação das estradas de ferro. A queda dos custos com o transporte, somados à liberação da mão-de-obra escrava do escoamento do produto para as lavouras, fez com que o preço do açúcar cubano sofresse uma queda brutal em relação ao de seus concorrentes. O próprio movimento do tráfico Atlântico de escravos não conseguia acompanhar o crescimento das necessidades de mão-de-obra escrava em Cuba, provocando a migração de colonos chineses e de escravos índios maias de Iucatã. ${ }^{33}$

As transações comerciais de escravos através da rota cubana eram feitas com o envolvimento de portos norte-americanos, no final dos anos 1850 e início dos 60. O navio saía de Cuba e ancorava, legalmente, nos portos de Nova Iorque, principalmente, Charleston e Nova Orleans. Estava repleto de açúcar cubano, que em grande parte era beneficiado nas refinarias norte-americanas. ${ }^{34}$ $\mathrm{O}$ agente comercial norte-americano o recebia em um daqueles três portos, encarregando-se do serviço de descarga do produto, bem como do embarque de um experiente marinheiro, também norte-americano. O navio seguiria, assim, para a África. Caso fosse abalroado por um cruzador inglês, "provaria” que não estava metido em tráfico de escravos, apresentando a documenta-

${ }^{33}$ Cf. KLEIN, Herbert S. A escravidão africana: América Latina e Caribe. São Paulo: Brasiliense, 1987, pp. 113-116. 
ção conseguida nos Estados Unidos da América que dizia que o navio pertencia ao tal marinheiro norte-americano. Na costa africana, o navio faria a compra dos escravos nos portos de Moçambique, principalmente, que seriam levados para Cuba. Quando o navio passasse pelas patrulhas britânicas, mais atentas ao comércio de escravos para Cuba durante o novo boom do açúcar, o navio assumiria novamente sua identidade cubana. Nos portos cubanos, parte deste ciclo comercial seria momentaneamente encerrado. ${ }^{35}$

Em 23 de janeiro de 1857 o presidente da província do Rio de Janeiro, Luiz Antonio Barbosa, recebeu um ofício "Reservado", no qual o ministro da Justiça, José Thomaz Nabuco de Araújo, denunciava a vinda de um navio armado para o Brasil. O brigue Barca havia saído de "Nova Iorque em fins de outubro" de 1856, "com destino à Costa da África, onde deveria receber de 500 a 600 africanos, já ladinos, para desembarcá-los na província do Rio de Janeiro". ${ }^{36} \mathrm{O}$ Ministro comunicou a notícia ao presidente daquela província, que ordenou que as "autoridades do litoral dessem mais eficazes providências a fim de obstar-se à semelhante desembarque.” O receio do suposto desembarque provocou a adoção de medidas radicais do ministro da Justiça seguinte, Franscisco Diogo Pereira de Vasconcelos, com relação à vigilância dos portos visados pelos traficantes de escravos. Em 28 de julho de 1857 o ministro "ordenou ao chefe de polícia da Corte que efetuasse o pagamento de 50 contos de réis ao Barão de Mauá, referentes à compra de um navio bateleira produzido pela Companhia de Ponta da Areia", de sua propriedade. A bateleira seria destinada à prevenção do "nefando crime de tráfico de escravos africanos para o Brasil", uma vez que notícias de desembarque giravam sobre os portos de Angra dos Reis e Mangaratiba. ${ }^{37}$

Notícias referentes a tal rota do tráfico de escravos envolvendo Nova Iorque, Cuba, costa da África e o Rio de Janeiro e São Paulo não paravam de chegar ao ministro da Justiça. Logo em seguida à aquisição da bateleira, em

\footnotetext{
${ }^{34}$ Cf. SCOTT, Rebecca J. Emancipação escrava em Cuba: a transição para o trabalho livre, 1860-1899. Rio de Janeiro, Campinas: Paz e Terra, Editora da UNICAMP, 1991, pp. 50-51.

${ }^{35}$ MURRAY, David. Odious commerce: Britain, Spain and the abolition of the Cuban slave trade. Cambridge: Cambridge University Press, 1980, pp. 246-249.

${ }^{36}$ AN, IJ1 - 867, Série Justiça/Gabinete do Ministro.

${ }^{37}$ AN, IJ1 - 867, Série Justiça/Gabinete do Ministro.
} 
20 de outubro de 1857 o ministro recebeu informação acerca do patacho norte-americano M. M. Standard, do qual era mestre de Deijamb. A notícia vinha da Ilha da Madeira, e dizia ainda que o tal navio era conhecido na ilha como destinado ao tráfico de escravos africanos. Mais uma vez, as autoridades do litoral do Rio de Janeiro foram avisadas para ficar mais vigilantes ainda sobre qualquer indício de possível desembarque de escravos. ${ }^{38} \mathrm{O}$ tráfico de escravos para Cuba havia realmente revigorado em 1857, e não mais estava nas mãos de comerciantes brasileiros na África, em Uidá, por exemplo, mas sim nas de uma nova companhia, a Expedición por África, fundada em Havana, e cujos barcos eram equipados nos Estados Unidos e navegavam sob as cores de sua bandeira. ${ }^{39}$

Passaram-se poucos anos e, em 13 de outubro de 1860, o então ministro da Justiça, João Lustosa da Cunha Paranaguá, foi informado pelo Consulado de Angola sobre a movimentação nos portos de Luanda de um tal Manoel Caetano dos Passos e Maurício Thomaz Bittencourt, reconhecidos como traficantes de escravos da rota acima falada. Tratavam-se dos capitães do navio Fortuna da África, que "em breve aportaria novamente na praia de Itacoatiara, em Itaipu, com mais escravos africanos". Segundo o ministro, caso aqueles traficantes fossem pegos, muito do crime do comércio ilegal de africanos para o Brasil poderia ser desvendado. ${ }^{40}$

Estas transações comerciais eram bem conhecidas nos Estados Unidos. No final dos anos 1850, deputados de Nova Iorque denunciavam que navios saíam do porto desta cidade com destino a Cuba, preparados para executar a transação que descrevemos. O cônsul inglês em Nova Iorque denunciou, por exemplo, que "no verão de 1859, o navio Emily saiu de Nova Iorque com todo o equipamento necessário para um traficante de escravos: 15.000 pés de madeira serrada, 103 tonéis de água fresca, 100 barris de arroz, 25 barris de bacalhau, 20 barris de porcos, 50 barris de pães, 150 caixas de arenque, duas cal-

\footnotetext{
${ }^{38}$ AN, IJ1 - 867, Série Justiça/Gabinete do Ministro.

${ }^{39}$ Cf. LAW, Robin. A comunidade brasileira de Uidá e os últimos anos do tráfico Atlântico de escravos, 1850-66. Afro-Ásia, n. 27, 2002, pp. 41-77, p. 58.

${ }^{40}$ AN, IJ1 - 869, Série Justiça/Gabinete do Ministro.
} 
deiras, dez dúzias de baldes e duas caixas de medicamentos". ${ }^{41}$ Por sua vez, o jornal nova-iorquino Continental Monthly noticiou, em janeiro de 1862, que:

"O número de pessoas envolvidas no tráfico de escravos bem como o montante de capital empregado no mesmo vai além do que podemos calcular. A cidade de Nova Iorque vinha sendo, até recentemente, o principal porto do mundo para este infame comércio; em relação à ela, as cidades de Boston e Portland são secundárias. Negociantes de escravos contribuíam largamente para a vitalidade comercial de nossa metrópole; contribuíram para enriquecer nossa organização política, e, muitas vezes, suas contas bancárias foram exauridas para cidades de eleições em Nova Jérsei, Pensilvânia e Connecticut". ${ }^{42}$

O mesmo navio poderia alongar sua viagem caso os escravos não fossem todos vendidos, ou caso tivesse que buscar escravos na China, contornando a América do Sul. Tal rota, apesar de oferecer mais difícil navegação, não envolvia a fuga da fiscalização exercida pelos navios britânicos sobre o tráfico de escravos para o Brasil. Afinal de contas, os navios britânicos estavam mais afastados da costa brasileira que os navios vindos de Cuba ou dos Estados Unidos. Anteriormente, vimos a notícia de que havia navios vindos de Cuba para comerciar escravos africanos no Rio de Janeiro. ${ }^{43}$ Desta forma, não seria uma conjectura estapafúrdia que o navio fantasma de nosso caso queria se livrar de um indesejável tripulante, sem que sua passagem pelo Rio de Janeiro fosse registrada. E conseguiu. Afinal de contas, tudo se passou na escuridão da madrugada, sem maiores registros que não a memória de pessoas comuns e de funcionários da Justiça.

\section{Considerações finais: metáforas e metonímias (a partir de uma acusação) atlânticas}

Uma vez feita a acusação, que resultou num processo criminal contra o juiz, o suposto "delinquiente" detonou um processo de relação entre termos. Ao procurar socorro no juiz, o capitão do navio fez uma denúncia contra uma

\footnotetext{
${ }^{41} \mathrm{Cf}$. THOMAS, Hugh. The slave trade: the history of the Atlantic slave trade, 14401870. New York: Touchstone, 1999, p. 770, além de todo o Cap. 36: "Cuba, the forward sentinel”, pp. 769-785.

${ }^{42}$ Apud. THOMAS, Hugh. The slave trade, pp. 771-772. Traduzido por mim.

${ }^{43}$ MURRAY, David. Odious commerce, p. 250.
} 
pessoa perigosa, se colocando, juntamente a sua tripulação, em oposição ao mesmo, isto é, como pessoas não perigosas, como aquelas que sofriam daquele perigo. Ao mostrar o ferimento supostamente feito com uma faca, o capitão se colocou como vítima do homem que havia sido preso por sua tripulação, ao passo que este era o alvo da providência das autoridades da Justiça em Macaé. Os escravos, além de marinheiros, estariam ali como vítimas de próximos golpes de faca, e não como mercadorias a serem vendidas naquela região. O navio não era posto, na situação criminosa que supostamente havia se desenvolvido no seu interior, como tumbeiro, mas sim como palco de uma "tentativa de assassinato". Os escravos ajudaram os policiais a retirarem o acusado, sendo supervisionados pelo capitão e pelo juiz. Tudo isso aconteceu a partir de uma experiência rápida e na penumbra da madrugada, às pressas de evitar um crime ainda maior. Com o sumiço do navio, tudo não passou de mera conjectura. Não atoa, o único documento que temos, ou melhor, que encontramos sobre este caso é parte de um processo aberto pelo "delinqüente" que passou ao papel de vítima, numa nova conjuntura, e o juiz ao de criminoso.

Neste sentido, gostaríamos de chamar atenção para a importância das acusações no Brasil Império. Muitas fontes documentais foram produzidas a partir de uma simples acusação, muitas vezes provenientes de boatos ou notícias de jornalistas locais, policiais, inspetores de quarteirão, lavradores, e até mesmo de escravos. Antes mesmo da instauração de um processo criminal, acusações motivaram investigações cuidadosas por parte de autoridades locais, muitas vezes chegando por carta ao conhecimento de ministros de Estado e chefes de polícia, na Corte. Antes mesmo de admitirmos a tese do medo de insurreições escravas da parte da elite imperial, temos que pensar o elemento social detonador de tanta documentação produzida por incertezas, baseadas em acusações. ${ }^{44}$ Estas acusações podem ser compreendidas como formas de se atingir inimigos ou adversários, provocando-lhes incômodas situações de constrangimento público, numa disputa de poder local. Vários são os casos de processos criminais envolvendo escravos e senhores, como também somente livres na Corte, que as investigações vêm depois de uma denúncia. Tais não provêm de desconfianças

\footnotetext{
${ }^{44}$ Sobre a visão senhorial de uma grande insurreição escrava, ver AZEVEDO, Célia Maria Marinho de. Onda negra, medo branco: o negro no imaginário das elites, século XIX. Rio de Janeiro: Paz e Terra, 1987, e vários trechos de COUCEIRO, Luiz Alberto. Bumerangue encapsulado.
} 
de um aparelho de inteligência, ou espionagem como ocorria entre Inglaterra e França no final do século XIX e no início do XX, que investigavam comportamentos sociais de maneira precavida, dentro de uma política de Estado.

A teoria antropológica da feitiçaria, que aborda este objeto de estudo a partir das acusações que detonam os conflitos entre as pessoas, na maioria dos casos nas sociedade africanas, nos ajuda muito a pensar o caso brasileiro de acusação, no século XIX. Existem variações diversas na teoria e na metodologia dos estudos de acusação e crença na feitiçaria, mas permanece como base de todos eles a pesquisa sobre o que faz de uma acusação eficaz, qual a crença que a sustenta. Evans-Pritchard, em seu clássico estudo sobre tal fenômeno entre os Azande, se preocupou em compreender uma teoria do conhecimento a partir das formas de acusação de feitiçaria. ${ }^{45}$ Seguindo suas trilhas, Gluckman e Douglas enveredaram pela análise de tais acusações como uma teoria moral e ética dos Zulu e dos Lele do Kasai, respectivamente, como uma forma de manutenção do equilíbrio das tensões entre os grupos internos. ${ }^{46}$ Fry conseguiu chegar aos seus informantes Shona, na Rhodésia, atual Zimbábue, a partir de uma acusação policial sobre o envolvimento político de conhecidos feiticeiros com partidos nacionalistas. ${ }^{47}$ Mais recentemente, Geschiere estudou a chamada "moderna feitiçaria" nos Camarões através as acusações de feitiçaria entre partidos políticos. ${ }^{48}$

A publicação organizada por Douglas, reunindo pela primeira vez historiadores e antropólogos dedicados aos casos de acusação e crença na feitiçaria é um marco teórico, para estudos contemporâneos, inclusive, como a coletânea

${ }^{45}$ EVANS-PRITCHARD, E. E. . Bruxaria, oráculos e magia entre os Azande (edição resumida, com uma introdução de Eva Gillies). Rio de Janeiro: Zahar Editores, 1978.

${ }^{46}$ GLUCKMAN, Max. "The logic of witchcraft." In: Custom and conflict in Africa. Oxford: Basil Blackwell, 1970, pp. 81-108; DOUGLAS, Mary. The Lele of the Kasai. London: Oxford University Press for the International African Institute, 1963. Ver também interessante auto-reflexão da autora sobre este trabalho em DOUGLAS, Mary. Os lele revisitados, 1987. Acusações de feitiçaria à solta. Revista Mana: estudos de antropologia social, v. 5 n. 2 outubro de 1999.

${ }^{47}$ FRY, Peter. Spirits of protest: spirit-mediums and the articulatino of consensus amongst the Zezuru of Southern Rhodesia. London, New York, Melbourne: Cambridge University Press, 1976.

${ }^{48}$ GESCHIERE, Peter. The modernity of witchcraft: Politics and the occult in postcolonial Africa. Carlotteville e Londres: University Press of Virginia, 1998. 
organizada pelos Comaroff, exatamente por consolidar a idéia de que a crença depende do ato de acusar alguém de feitiçaria, e a acusação, por sua vez, depende da eficácia da crença na acusação. É aí que o jogo começa. ${ }^{49}$ É aí que o historiador social da sociedade escravista no Brasil tem a oportunidade de perceber como grande parte da documentação produzida assim o foi num sistema de acusações que obtiveram eficácia no sistema legal brasileiro. Tais acusações independem de ser ou não de feitiçaria, ou de algum crime que tivesse previsto no Código Criminal, posto que muitas acusações eram feitas com base no que as pessoas acreditavam ser crime no cotidiano de suas vidas. Ou seja, estavam ligadas à construção social da acusação, que dependia da culpa que, por sua vez, estava ligada à legitimação social de certos tipos de pessoa como acusadoras, bem como outros acusados.

Em nosso caso, um navio, em época de tensão das autoridades brasileiras e internacionais sobre tráfico Atlântico de escravos, fundamentalmente para regiões compradoras desta mão-de-obra, jamais poderia aportar com escravos sem ser registrado por uma autoridade da Justiça, que chegou a estar abordo. Jamais um navio podia ser fantasma. Este juiz jamais podia escapar, após tamanha negligência, de um sistema de acusações como havia no Brasil Império. A única coisa que escapou foi o navio das autoridades imperiais. Mas não de nós, e nem de uma acusação atlântica.

${ }^{49}$ DOUGLAS, Mary. Witchcraft confessions and accusations. London, New York: Tavistock Publication, 1970; COMAROFF, Jean \& COMAROFF, John (eds). Modernity and its malcontents: ritual and power in postcolonial Africa. Chicago: The University of Chicago Press, 1993. 